\title{
Analysis of Dynamic Behavior of Full-Scale Shaking Table Specimen to Evaluate a Strong Near-Source Earthquake
}

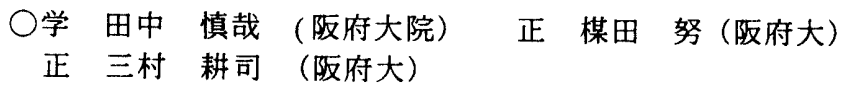

\author{
Shinya TANAKA, Osaka prefecture University, 1-1, Gakuencho, Sakai \\ Tsutomu UMEDA, Osaka prefecture University \\ Kouji MIMURA, Osaka prefecture University
}

\begin{abstract}
The great Hanshin-Awaji earthquake has brought a large number of structual failures, and some of them are considerably different from the failures in the past earthquakes. One of them is the brittle fracture of steel box column of a high building. In this study, to clarify the fracture process in large members such as the steel box column and $\mathrm{H}$-steel beam subjected to severe land movements caused by strong near-source earthquake, dynamic behavior of full-scale shaking table specimen was analyzed. In the analysis, specimen was modeled in detail in order to compare analytical results with the experimental results. Through the comparisons, an effective earthquake-proof construction was discussed.
\end{abstract}

Key Words : Near-source earthquake, Dynamic failure, Full-scale shaking table test, Finite element method

\section{1. 緒言}

直下型地震特有の地震動初期の激しい上下. 水平方向摇 れにより, 大型構造物の一部にその地震動初期に対応した 過渡応答時において, き裂や部分的破壊が生じ，その後の 引き続く摇れにより, 大きな破壊や破損が生じた可能性が 報告されている(1).

しかし，現状では構成部材の破壊条件が解明されていな いため, 破壊に対する設計規範が確立されていない。一方, 破壊の発生しやすい応力集中箇所における塑性化を避ける ために，新しい構造形式を開発することも考えられる。

本研究では鋼構造建築物が破壊に対してどの程度の抵抗 能力を有しているのか, 破壊抑止のためにはどのような手 法が有効であるかを解明するために行われた, 鋼構造物骨 組の実大振動台実験に関して, その有限要素モデルを作成 して三次元挙動を解析し，実験との比較を行うとともに、解 析の妥当性について検討した. これらの結果に基づいて, 構 造骨組の性能はそのままで, 制振部材を追加することによ り，既存建物の架構内に制振部材を設置した場合の耐震効 果について検討を行った。

\section{2. 実大振動台試験体の解析}

\section{1 実大振動台実験の概略}

山田ら(2)は，鋼構造建築物の梁端接合部における破壊現 象を解明し, 設計時に接合部に期待できる変形能力を評価 するために，以下のような実大振動台実験を行った。実構 造物の骨組の部分架構に注目して，これを試験体として製 作し，実大の構造部材・接合部に対する動的破壊現象を再 現した。実験装置の概略および概念を図 1(a), (b) に示す. 実験装置は振動台からの入力によって慣性力を生み出す重 錘と重錪を支える加振フレーム，重鍾および加振フレーム に作用する重力を支える積首ゴム, 試験体, そして加振 レームから水平力を試験体に伝える加力梁から構成される. また，加振に用いられる入力波は，短時間に大きな入力工 ネルギーがもたらされる直下型の地震波として，阪神・淡 路大震災時の神户海洋気象台で記録された加速度から求め られた速度に倍率を掛けて入力レベルを調整したものを用 いた.

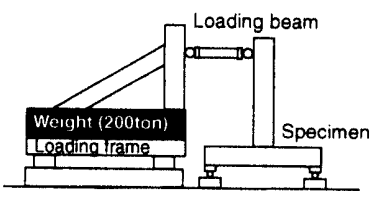

(a) Overview

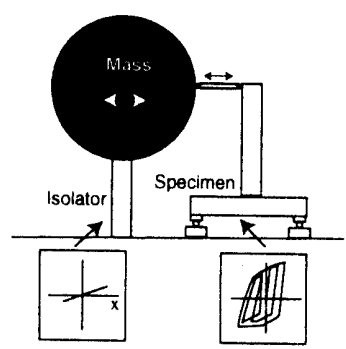

(b) Schematic drawing

\section{2 実大振動試験体の解析モデル}

解析に用いた試験体および加振・支持部分の概略を図 2(a)に，有限要素モデルを図 2(b) に示す，モデル全体の節 点数は19973であり，要素数は13388である，試験体は，柱 に相当する箱形柱と梁に相当する溶接組立 $\mathrm{H}$ 形鋼からなる T形部分架構である. 柱材断面はUB-500×500 × $22(\mathrm{~mm})$, 梁材断面は $\mathrm{H}-500 \times 300 \times 16 \times 25(\mathrm{~mm})$ であり，材料特性 は密度 $\rho=7890 \mathrm{~kg} / \mathrm{m}^{3}$, ポアソン比 $\nu=0.28$, さらに真応力. 真ひずみ関係については, 箱形柱はSTKR490 相当, 梁は SM490A 相当のものを用いた。用いた材料の真応力一真ひ ずみ関係を図 3 に示す。

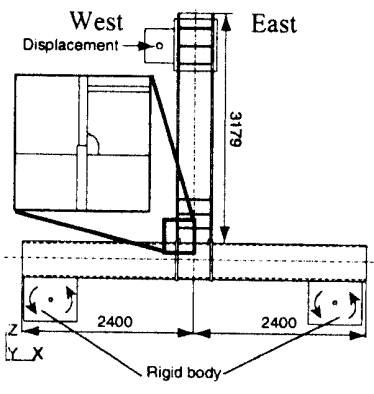

(a) Overview

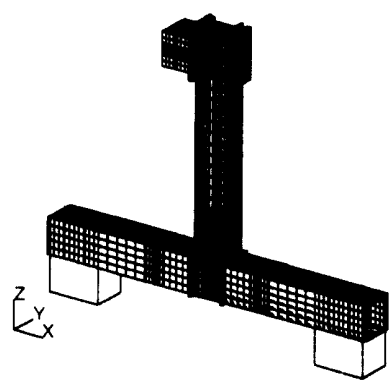

(b) Analytical model
Fig.2 Specimenmodel and boundary conditions 


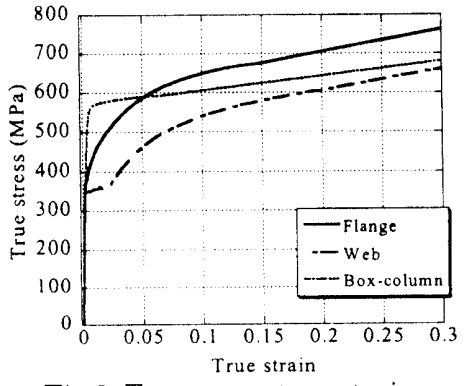

Fig.3 True stress-true strain curves employed in the analysis

\section{3 境界条件}

本解析では，試験体下部を図 2(a)に示すように剛体の上 に固着し，その剛体の中心の回転はY 軸回りのみ許容して いる.なお，剛体の中心の並進運動は $X, Y, Z$ 方向之も拘束 されるものとした．加力点は加振梁の一部を弾塑性体の直 方体でモデル化し，その回転中心にモデル化した弾性ピン に, 図4に示すような, 実験において計測された加力点位置 における変位時間履歴を入力した。ピンと直方体との境界 は，接触境界（摩擦なし）上して取り扱った。なお図4中の $\mathrm{t}_{\mathrm{F}}$ は，実験において試験体のスカラップ周辺で破壊が生じた 時刻を示したものである。

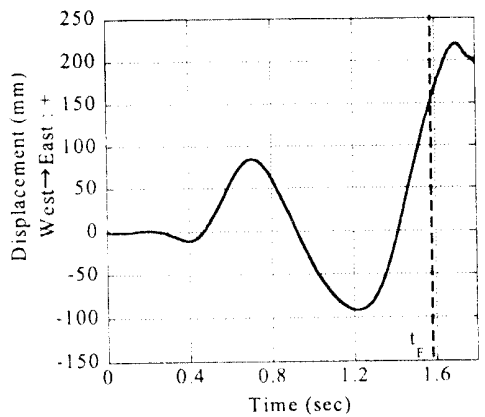

Fig.4 Time history of input displacement

\section{4 解析結果}

図 5 は実験で破断が生じた逆 $\mathrm{T}$ 字接合部周辺でひずみ測 定用に用いられたゲージの位置（NO.3）を示している．眓 6にこのゲージ位置において実測されたひずみ一時間履歴と 今回の計算によって得られたひずみ一時間履歴との比較を 示す。本解析で得られたひずみ一時間履歴と実験で計測さ れたひずみ一時間覆歷はよく一致して㧍り，計算結果は妥 当なものと考えられる。 また時刻 $\mathrm{t}_{\mathrm{F}}$ においては両者とも著 しく大きなひずみが生じているが，このときの逆 T字接合 部周辺の応力分布は図7に示すようになった。破断䇢所に相 当する部分では最大 $720 \mathrm{MPa}$ もの高い応力が生じており，こ れは破断が生じるに十分高い応力值であると考える。

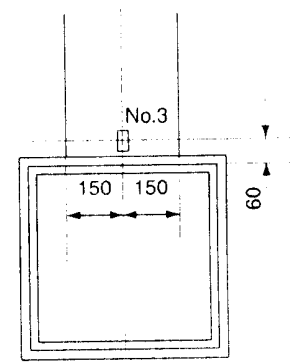

Fig.5 Location of strain gauge (West flange)

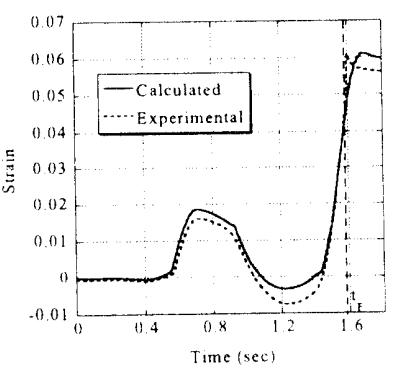

Fig.6 Example time history of strain (No.3)
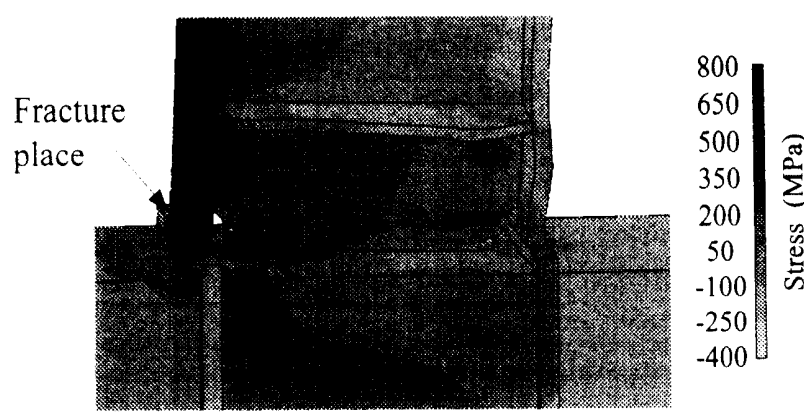

Fig.7 Example of distribution of stress $\left(t_{F}=1.58 \mathrm{sec}\right)$

\section{3. 制振部材を設置した試験体}

実大振動試験体の解析結果において，逆 T字接合部で応 力集中が起こっており，また，松本らによる実大振動台実 験(3)においても，接合部において破壊が生じた結果が得ら れている。そこで，接合部付近の忘力集中を低隇する目的 で制振部材を追加した場合について検討した。図8に制振部 材を設置した試験体の解析モデルの概略を示す。制振部材 は一部箱形の柱で構成され，材料は低降伏点鋼である LYP100相当とした．その真応力一真ひずみ関係を図9に示 す。その他の材料特性や境界条件は図2で示したモデルと同 様である。なお，結果については紙面の都合上ここでは割 愛し，発表当日に詳細を示す。

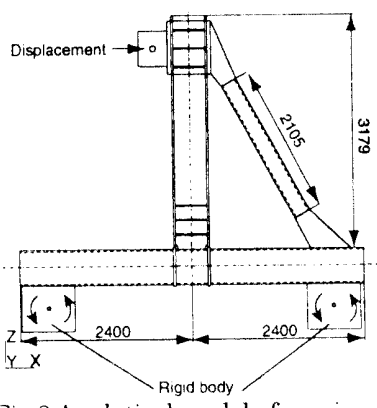

Fig.8 Analytical model of specimen

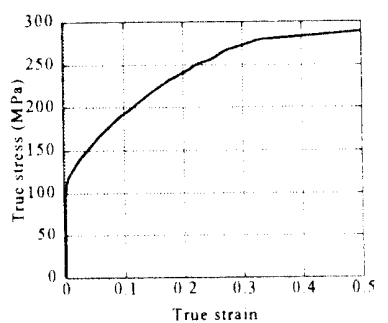

Fig.9 True stress-true strain curves of LYP100

\section{4. 結言}

構造部分骨組の実大振動台実験の有限要素モデルを用い て解析を行い，実験結果と比較することによって，鋼構造 建築物が破壊に対してどの程度の抵抗能力があるのか検討 を行った。これらの結果に基づいて，忘力集中が起きやす く破壊が発生しやすい梁端接合部の応カレベルを抑えるた めに低降伏点鋼を材料とする制振部材を設置した耐震構造 について検討をおこなつた。

\section{文 献}

(1) Tanimura, S., Mimura, K., Nonaka, T., and Zhu, W., Dynamic Failure of Structures Due to the Great Hanshin-Awaji Earthquake, Int. J. of Impact Eng., 24 (2000), pp.583-596.

（2）山田・ほか5名，夷大振動台実験による建築鋼構造の脆性破壊過 程解明と破壊抑此策の㭘証その1。実験計画，第3回構造物の 破壊過程解明に基づく地震防災性向上に関するシンポジウム論 文集, (2002.2), pp.119-124.

(3)松本・活少 5 名，実大振動台実験による建築鋼構造の脆性破壊過 程解明亡破壊抑止策の検証その2. 破壊シリーズの実験結果, 第3 回構造物の破䘫過程解明に基づく地震防災性何上に関する シンポジウム論文集, (2002.2), pp.125-130. 